\title{
ANALISIS SISTEM ACCURATE UNTUK MENGELOLA DATA PENJUALAN STUDI KASUS PT. BETOMIX NUSANTARA LESTARI
}

\author{
Syepry Maulana ${ }^{1}$, Rika Rahmawati ${ }^{2}$ \\ 1,2,3 Program Studi Teknnik Informatika, Fakultas Teknik, Universitas Muhammadiyah Tangerang Jalan Perintis \\ Kemerdekaan 1/33 Cikokol Kota Tangerang \\ Email : shevrie18@gmail.com ${ }^{1}$, rikarahmawati525@gmail.com²
}

\begin{abstract}
Article history

Received May 22, 2020

Revised May 15, 2019

Accepted May 31, 2019

Available online May 31, 2020

Keywords

System,

Accurate,

Selling

More and more technological developments that continue to occur cause information system technology to become a necessity that is owned by every company and even become the main thing in carrying out an operational activity, a problem that often arises namely the frequent occurrence of recording errors on sales data reports, lack of good storage of data documents sales and less efficient in terms of time in recording sales transactions. The method used is the method of interview / interview, literature and observation. With the implementation of an accurate system at PT. Betomix Nusantara Lestari, the company experienced a very positive impact, ranging from sales to be neater starting from making POs, receipt of goods and sales invoices, as well as purchases.
\end{abstract}

Riwayat

Diterima 22 Mei 2020

Revisi 15 Mei 2020

Disetujui 31 Mei 2020

Terbit 31 Mei 2020

Kata Kunci

Sistem,

Accurate,

Penjualan

\begin{abstract}
Abstrak
Semakin banyaknya perkembangan teknologi yang terus terjadi menyebabkan teknologi sistem informasi menjadi sebuah keharusan yang dimiliki oleh setiap perusahaan bahkan menjadi hal yang utama dalam menjalankan suatu kegiatan operasional, masalah yang sering muncul yaitu Sering terjadinya kesalahan pencatatan terhadap laporan data penjualan, Kurang baiknya penyimpanan terhadap dokumen data penjualan dan Kurang efisien dari segi waktu dalam mendata transaksi penjualan. Metode yang digunakan yaitu dengan Metode Interview / wawancara, Kepustakaan dan Observasi. Dengan diterapkanya sistem accurate pada PT. Betomix Nusantara Lestari, perusahaan mengalami dampak yang sangat positif, mulai dari penjualan jadi lebih rapi mulai dari pembuatan PO, penerimaan barang dan faktur penjualan, begitupun dengan pembelian.
\end{abstract}

\section{PENDAHULUAN}

Semakin banyaknya perkembangan teknologi yang terus terjadi menyebabkan teknologi sistem informasi menjadi sebuah keharusan yang dimiliki oleh setiap perusahaan bahkan menjadi hal yang utama dalam menjalankan suatu kegiatan operasional, sehingga aktivitas dalam mengerjakan pekerjaan lebih terarah, dan kemudahan dalam pengambilan keputusan. Banyak perusahaan telah menerapkan teknologi informasi untuk kelancaran aktivitas operasional dan salah satunya PT Betomix Nusantara Lestari.

Accurate adalah sebuah software akuntansi yang diperuntukkan bagi Usaha Kecil Menengah
(UKM) yang dibuat secara terpadu dari beberapa modul. Aplikasi ini menyediakan berbagai fasilitas seperti penjualan, pembelian, persediaan barang, buku besar, kas bank, aktivasi tetap, pembiayaan pesanan, klaim barang, manajemen proyek dan laporan keuangan.

Dengan diterapkanya sistem accurate pada PT. Betomix Nusantara Lestari, perusahaan mengalami dampak yang sangat positif, mulai dari penjualan jadi lebih rapi mulai dari pembuatan $\mathrm{PO}$, penerimaan barang dan faktur penjualan, begitupun dengan pembelian. Arus data penjualan di Pt. Betomix Nusantara Lestari, dengan adanya sistem Accurate, file-file tersusun dari penerimaan dan pengeluaran kasnya. Pengeluaran kas menggunakan sistem 
Accurate, mulai dari berkas dari pegawai sampai penginputan dalam sistem

Masalah yang sering muncul yaitu Sering terjadinya kesalahan pencatatan terhadap laporan data penjualan, Kurang baiknya penyimpanan terhadap dokumen data penjualan dan Kurang efisien dari segi waktu dalam mendata transaksi penjualan.

\section{TINJAUAN PUSTAKA}

Sistem informasi adalah kumpulan dari sub-sub sistem yang saling terintegrasi dan berkolaborasi untuk menyelesaikan masalah tertentu dengan cara mengolah data sehingga memiliki nilai tambah dan bermanfaat bagi pengguna (Taufiq, 2018)

Penjualan merupakan suatu usaha yang dilakukan untuk mendistribusikan barang kebutuhan yang telah dihasilkan oleh produsen kepada konsumen yang memerlukan dengan memperoleh jasa berupa uang. Penjualan dapat dilakukan dengan cara antara lain :

a. Penjualan Langsung

Cara penjualan dimana penjual langsung berhubungan atau berhadapan dengan pembeli. Pembeli dapat langsung mengemukaksan keinginannya bahkan sering terjadi tawarmenawar harga untuk mencapai kesesuaian.

b. Penjualan Tidak Langsung

Dapat terjadi jika terdapat masalah antara lain : jarak antara lokasi penjual dan pembeli cukup jauh, respon masyarakat terhadap sebuah iklan atau katalog, terbatasnya waktu antara penjual dan pembeli. Contoh : melalui telpon, email dan fax.

Sistem Penjualan adalah sistem yang melibatkan sumberdaya dalam suatu organisasi, prosedur, data, serta sarana pendukung untuk mengoperasikan sistem penjualan, sehingga menghasilkan informasi yang bermanfaat bagi pihak manajemen dalam pengambilan keputusan. Destriana dan Rafiudin (2019)

Dalam konteks aktualisasi pendapat di atas, perencanaan strategis/penjualan tentu perlu menganalisis tuntutan perkembangan lingkungan strategis, yang langsung atau tidak langsung bersentuhan dengan pelaksanaan tugas pokok dan fungsi analisis yang dimaksud inidapat dilakukan dengan pendekatan analisis S-WOT, yakni analisis terhadap factor-faktor lingkungan internal dan lingkungan eksternal.

Sistem adalah suatu kumpulan atau himpunan dari unsur, komponen atau variabel yang terorganisasi, saling berinteraksi, saling tergantung satu sama lain dan terpadu. (Permana, 2016).

UML (Unified Modeling Language) adalah bahasa spesifikasi standar yang digunakan untuk mendokumentasikan, menentukan, dan membangun perangkat lunak.UML adalah metodologi mengambang dalam sistem berorientasi objek dan juga alat untuk mendukung pengembangan sistem. Berdasarkan beberapa pendapat di atas dapat disimpulkan UML (Unified Modeling Language) adalah bahasa pemodelan yang digunakan untuk merancang dan mendokumentasikan sistem perangkat lunak (Destriana, Permana, Legawa, Irawan, 2018)

\section{METODE PENELITIAN}

Metode-metode yang digunakan untuk mendapatkan informasi dan data-data yang di perlukan adalah sebagai berikut :

- Metode Interview / wawancara.

Metode wawancara yaitu pengumpulan data dengan jalan tanya jawab lisan secara sepihak yang dikerjakan secara sistematis dan berlandaskan pada tujuan penelitian.

- Metode Kepustakaan.

Yaitu dengan mengumpulkan berbagai sumbersumber referensi baik berupa buku, artikel dan sumber-sumber lainnya sebagai acuan analisis.

- Metode Observasi.

Disamping wawancara, penelitian ini juga melakukan metode observasi. Obsevasi adalah pengamatan dan pencatatan secara sistematik terhadap unsur-unsur yang tampak dalam suatu gejala-gejala dalam objek penelitian.

- Metode Kearsipan.

Yaitu menggunakan arsip-arsip yang ada di

PT Betomix Nusantara Lestari data-data ini meliputi:

- $\quad$ Profil, visi dan misi dan struktur organisasi PT Betomix Nusantara Lestari. 
- Data Penjualan Beton dan data laporan lainya.

- Metode Analisis

\section{HASIL DAN PEMBAHASAN}

\section{Analisa Sistem yang berjalan}

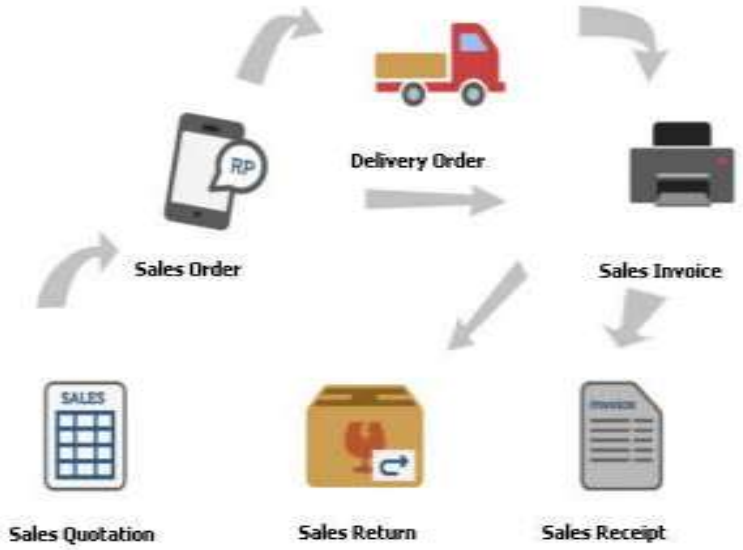

Gambar 1 Flowchart sistem yang berjalan

Pada Gambar di atas tampak siklus dari Penjualan yang ada di ACCURATE, aktifitas dari penjualan ini di mulai dari Sales Quotation [Penawaran Penjualan] sampai dengan Sales Receipt [Penerimaan Pelanggan]. Sebelum memulai aktifitas Penjualan, ada beberapa data dan setup yang harus disiapkan. Berikut data dan setup yang diperlukan :

a. Data Pelanggan [Customer] telah dibuatkan dengan memilih currency, terms, tax dan informasi lainnya secara benar.

b. Data Item [Inventory Parts dan Non Inventory Parts] telah disediakan dan di buat dengan pengaturan GL account yang benar.

c. Kode Pajak [Tax Code] yang terhubung dengan data pelanggan dan item serta pengaturan akun Pajak yang benar.

d. Form Template yang sudah di desain sesuai dengan ketentuan yang diinginkan.

\section{SALES QUOTATION (PENAWARAN PENJUALAN)}

Sales Quotation Form adalah formulir penawaran penjualan yang berfungsi untuk mencatat berbagai jenis barang yang ingin dan dapat dijual kepada customer (pelanggan).

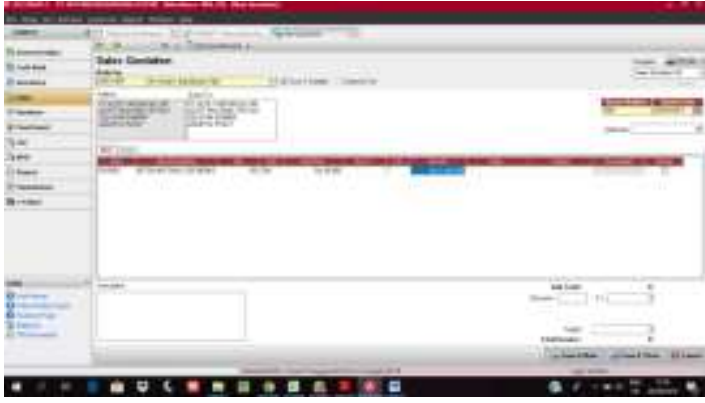

Gambar 2 Activity Sales Quatation

\section{SALES ORDER ( PESANAN PENJUALAN )}

Sales Order form adalah formulir yang digunakan untuk mencatat pesanan yang diterima dari Customer [Pelanggan], pesanan tersebut biasa dalam bentuk Purchase Order (PO).

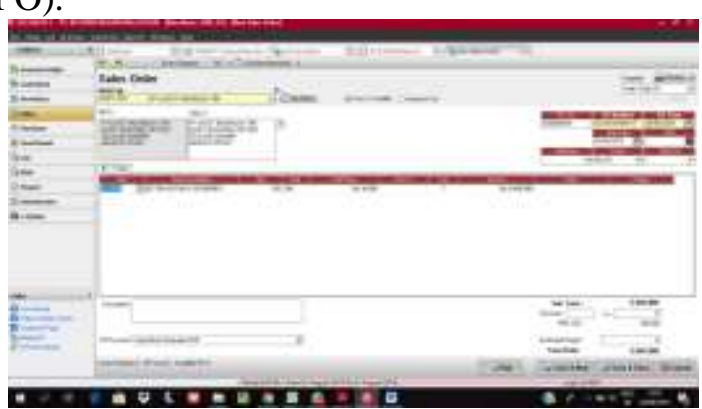

Gambar 3 Activity Sales Order

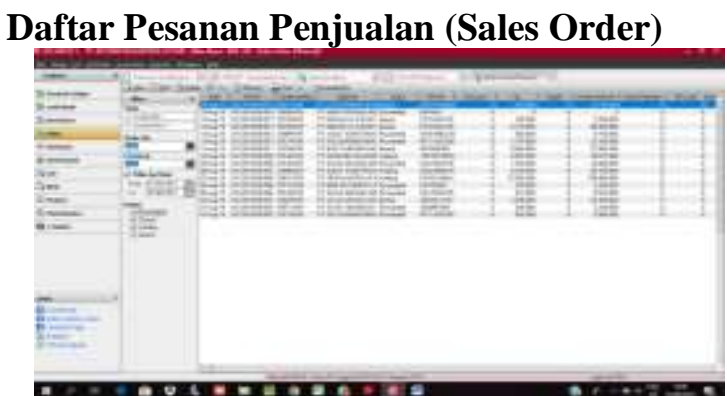

Gambar 4 Daftar Pesanan Penjualan

\section{DELIVERY ORDER ( PENGIRIMAN PESANAN )}

Formulir Delivery Order (DO) adalah formulir yang dapat Anda gunakan untuk mencatat aktifitas pengiriman barang yang dipesan pelanggan. 


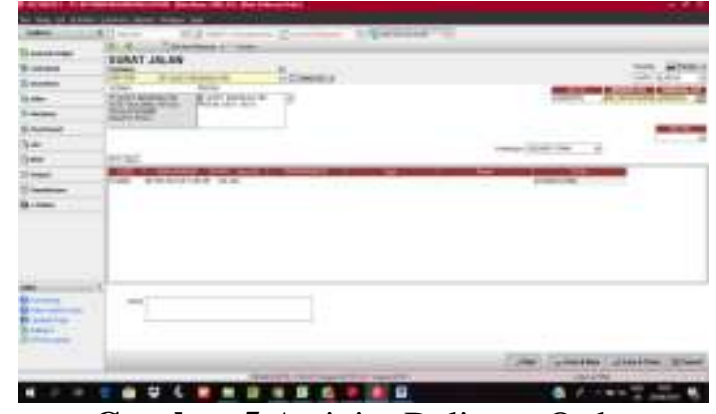

Gambar 5 Activity Delivery Order

\section{Daftar Pengiriman Pesanan (List Of Delivery Order)}

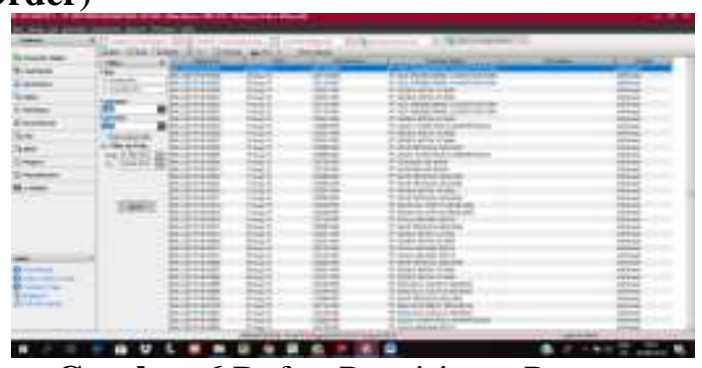

Gambar 6 Daftar Pengiriman Pesanan

\section{SALES INVOICE FAKTUR PENJUALAN}

Sales Invoice (SI) adalah faktur penjualan kepada customer, dimana pada aktifitas ini terjadi pengakuan Piutang Customer. SI biasa dibuat berdasarkan atas Sales Quotation (Penawaran), Sales Order (Pesanan) atau Delivery Order (Pengiriman Barang), tetapi dapat juga langsung dibuat dengan mengisi item yang akan dijual.

\section{Formulir Sales Invoice}

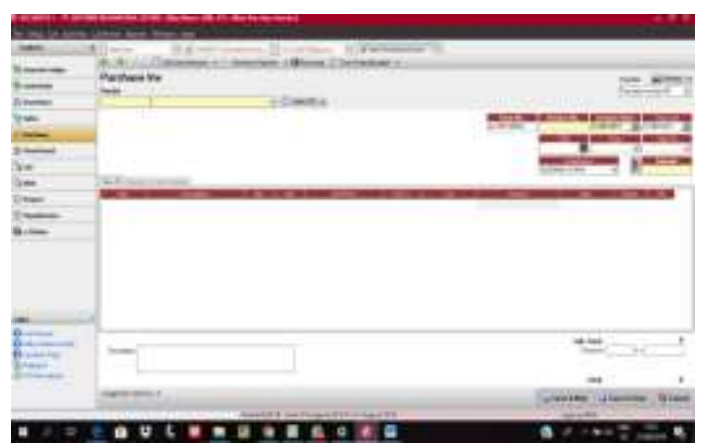

Gambar 7 Activity Sales Invoice
Daftar Faktur Penjualan (List Of Sales Invoice)

Semua formulir Sales Invoice yang telah Anda buat baik yang sudah lunas maupun yang masih outstanding akan disimpan atau direkap dalam satu Tabel yang disebut Daftar Faktur Penjualan (List Of Sales Invoice).

Daftar Sales Invoice dapat dibuka dari menu utama List - Sales - Sales Invoice (Daftar Penjualan - Faktur Penjualan).

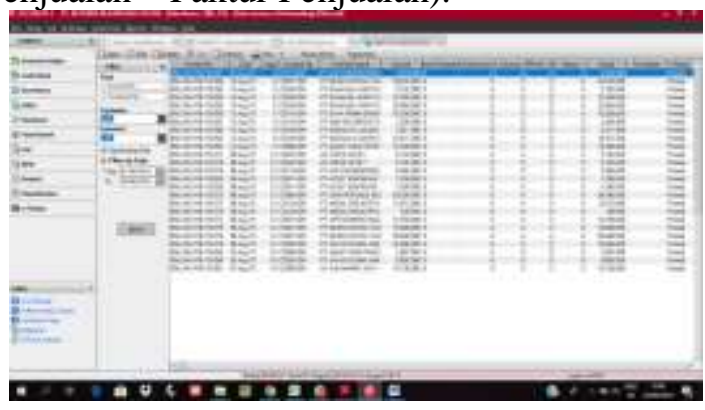

Gambar 8 Daftar Faktur Penjualan

\section{Penggambaran Sistem}

Untuk menganalisis sistem yang berjalan, pada penelitian kali ini digunakan program Unified Modelling Language (UML) untuk menggambarkan prosedur dan proses yang berjalan saat ini, sebagai berikut:

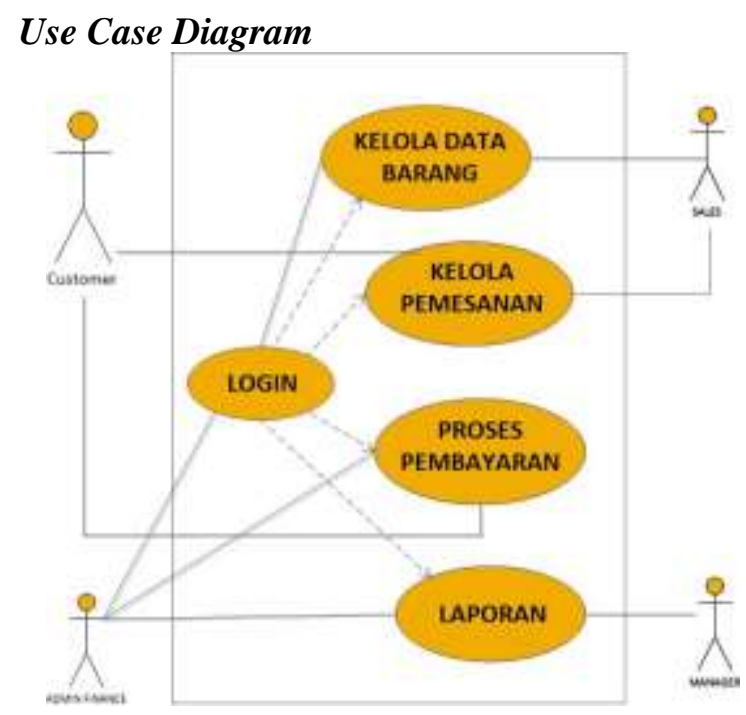

Gambar 11 Use Case Diagram 
Use Case Diagram Sistem berjalan Berdasarkan gambar 4.11 Use Case Diagram yang berjalan diatas terdapat :

a. $\quad 1$ (satu) Sistem yang mencakup seluruh kegiatan dari pemesanan barang sampai dengan penjualan.

b. 4 (empat) Actor yang melakukan kegiatan diantaranya : Customer, Sales, Adm Finance dan Manager.

c. 6 (Enam) Use Case yang dilakukan diantaranya : Login, Kelola Data Barang, Kelola Pemesanan, Pembayaran, Laporan dan Cetak.

\section{State Chart}

State Chart Diagram Login

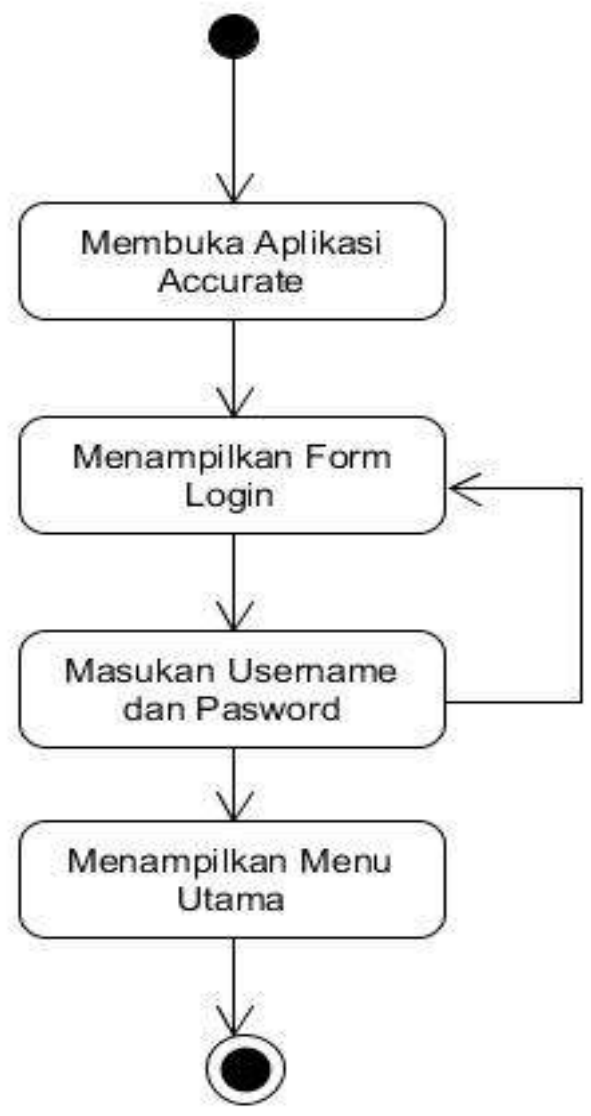

Gambar 12 State Chart Diagram Login

\section{Activity Diagram}

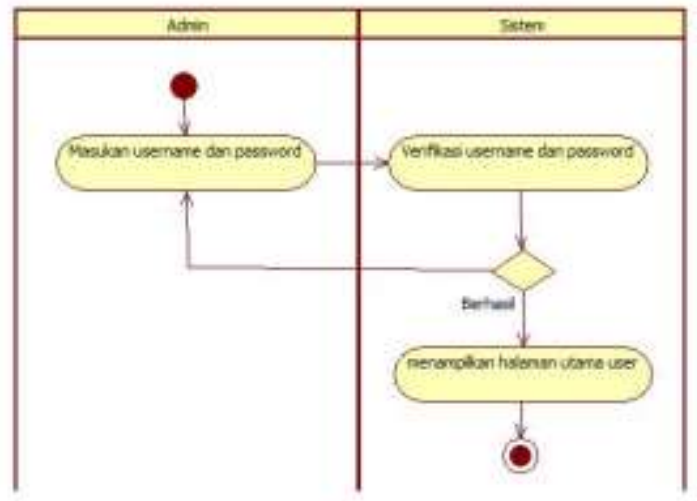

Gambar 13 Activity Diagram Login

\section{Squence Diagram}

Squence Diagram Login

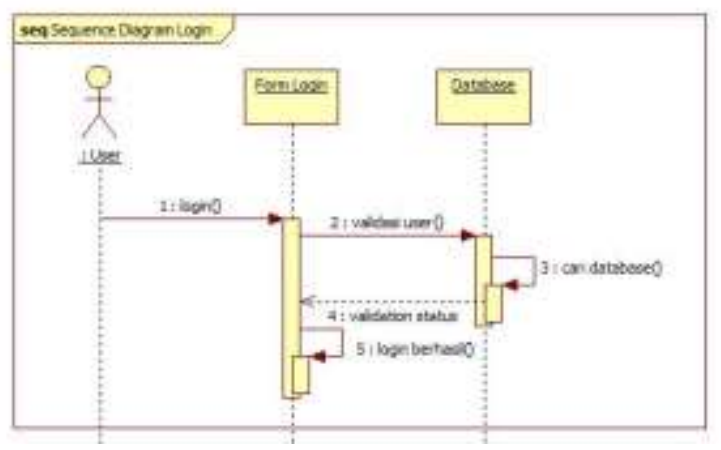

Gambar 14 Sequence Diagram Login

\section{Class Diagram}

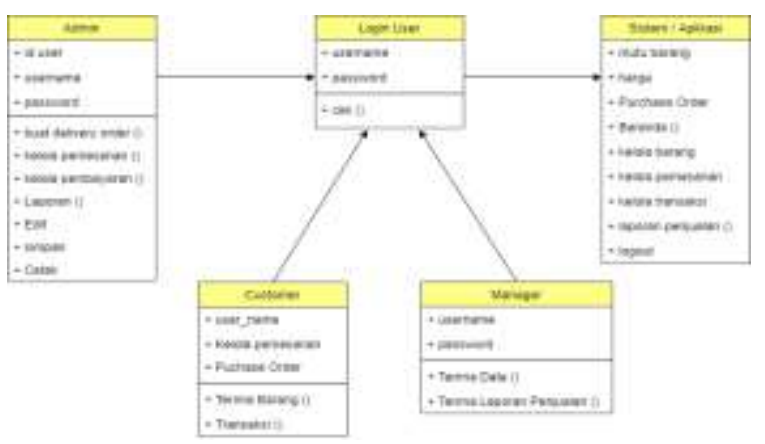

Gambar 15 Sequence Diagram Pembayaran 
Design Tampilan

Tampilan Login

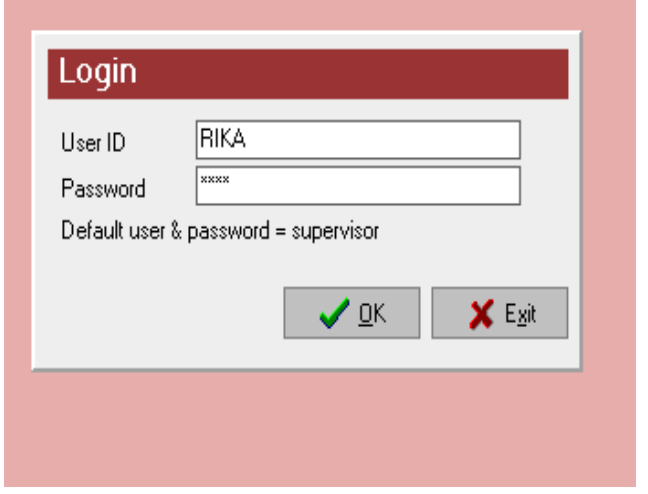

Gambar 16 Tampilan Login

\section{KESIMPULAN}

Setelah memepelajari masalah yang dihadapi dan juga solusi pemecahan yang diusulkan, maka penulis dapat menyimpulkan bahwa :

1. Dengan aplikasi Accurate yang terkomputerisasi maka dapat mengurangi kesalahan pencatatan dan perhitungan yang sering dilakukan oleh manusia (Human Error).

2. Dengan aplikasi Accurate yang terkomputerisasi dapat mempercepat pengolahan data dan pembuatan laporan.

3. Dengan aplikasi Accurate yang terkomputerisasi dapat mempermudah kegiatan pembelian dan penjualan.

4. Dengan aplikasi akuntansi yang terkomputerisasi dapat meningkatkan pelayanan kepada pelanggan denga terpenuhinya kebutuhan pelanggan denga cepat.

5. Dengan aplikasi akuntansi yang terkomputerisasi dapaat membantu pemimpin dalam mengambil keputusan dengan menyajikan informasi yang akurat, relevan dan tepat waktu yang sangat dibutuhkan oleh pimpinan.

\section{REFRENSI}

Destriana, R. 2019. Analisis dan Perancangan EBisnis dalam Budidaya dan Penjualan Ikan Cupang Menggunakan Metodelogi Overview. JIKA (Jurnal Informatika) Vol. 3 No.1 2019 ISSN 2549 - 0710.

Destriana, R., Permana, A, A., Legawa, S, D,. dan Irawan, H. 2019, Security system development for vehicle using the method of "mail notification" at villa Rizki Ilhami Tangerang residential, IOP Conference Series: Materials Science and Engineering 012124, Vol 508 No 1, IOP Publishing doi:10.1088/1757-899X/508/1/012124

Permana, A. A. (2016). Rancangan Sistem Informasi Simpan Pinjam Pada Koperasi Guru dan Pegawai SMP Negeri 45 Jakarta. JIKA (Jurnal Informatika) Vol. 1 No.2 2017 ISSN 2549 - 0710.

Taufiq, R., 2014. Penilaian Kinerja Dosen Dalam Bidang Belajar Mengajar Di Fakultas Teknik Universitas Muhammadiyah Tangerang. Jurnal Faktor Exacta Vol. 5 No. 1: 77-85 ISSN: 1979 276X.

Taufiq, R. 2018. "Pengantar Sistem Informasi". Jakarta. Mitra Wacana Media. 